\title{
Innovation Strategy of Small Medium Enterprise (SME) Through Public-Private Partnership in Depok City
}

\author{
Anita Maulina ${ }^{a, 1, *}$, Maya Puspita Dewi b,2 \\ 1,2 Institut Ilmu Sosial dan Manajemen STIAMI, Jakarta, Indonesia \\ Email : anita@stiami.ac.id ${ }^{1}$, maya.pd@stiami.ac.id ${ }^{2}$ \\ Corresponding Author
}

ARTICLE INFO

\section{Article history}

Received 2020-08-29

Revised 2020-09-12

Accepted 2020-09-19

\section{Keywords}

Inovasi, UKM, kemitraan, publikswasta

\begin{abstract}
The rapid growth of SMEs in Depok City is not accompanied by the increase in the capacity of the SMEs itself, especially in terms of innovation. The limited resources that SMEs have, can be supported by the existence of public-private sector partnerships. This research is a qualitative research with data collection techniques through interviews, observation, and literature study. The results show that public-private sector partnerships in Depok City have not been successful in increasing the capacity of SMEs to innovate. This is because the partnership is limited to providing infrastructure and focuses on increasing temporary income. Therefore, the public-private sector partnership should focus on more technical assistance in increasing added value to ensure business continuity for a longer period.
\end{abstract}

\section{INTRODUCTION}

In a regional context, Small and Medium Enterprises (SMEs) make a major contribution in creating new business fields in the regions and supporting efforts for sustainable economic growth (Janda, Rausser, \& Strielkowski, 2013; Sitharam \& Hoque, 2016). Moreover, in the face of a highly competitive economic situation, the SME sector is required to be more active and dynamic as an engine of social economic growth. However, due to its small business form, it creates vulnerability in facing market challenges due to significant problems with regard to human resources, technological capabilities, and financial access (Business, 2016; UNIDO, 2004; Vanags, Ābeltina, \& Zvirgzdina, 2018). The Chamber of Commerce and Industry (KADIN) revealed the results of a survey conducted by the Asian Development Bank (ADB) in July 2020, which stated that $30 \%$ of SMEs experienced disruption in domestic demand, $20 \%$ experienced production disruptions, and $14.1 \%$ experienced contract cancellations. Furthermore, it was stated that of the 60 million SME entrepreneurs in Indonesia, around 30 million were closed during the COVID-19 pandemic.

For this reason, to support the growth and development of SMEs in the regions, it is necessary to support policies that give priority to SMEs, which ensure flexibility and innovation in order to create diversification of business activities. Support that is intended is the support provided by local governments such as financial support, consultation forums, and the formation of partnership networks aimed solely for the growth of SMEs (Niño-Amézquita, Dubrovsky, \& Jankurová, 2017; Ruchkina, Melnichuk, Frumina, \& Mentel , 2017).

Talking about partnerships, it is believed to be a concept that is able to answer the innovation challenges that must be carried out by SMEs in facing market challenges (Halimani, Mazava, \& Dzapasi, 2019). Lack of understanding of the importance of building partnerships, in this case public and private sector partnerships in the development of SMEs, has resulted in the development of SMEs not maximally, and the potential of the SMEs themselves have not been explored (Balkans, 2019). In fact, partnerships that are built can be a lever for innovation and the development of SMEs (Hussain, Sib, \& Wangc, 2010), and partnerships can be a solution to problems that are directly related to the populist sector (Dewi \& Tuswoyo, 2020). 
This study discusses strategies for developing SME innovation in Depok City through partnerships between the public and private sectors in the framework of sustainable economic development. The scope of research is limited only from 2018-2020 considering that since the end of 2017, Depok City has committed to provide support for the development of SMEs by carrying out the 1000 kiosk program for SMEs whose completion target is in 2020. Depok City was taken as a research locus by considering its strategic position as a capital buffer area with a fairly high economic growth rate (BPS, 2019). This is inseparable from the existence of SMEs in Depok City which has a very strong influence on regional economic development, and has become a major supporter of the economic activity in the region, especially during the Covid 19 pandemic. This condition is certainly an opportunity and challenge for the Depok City government to can align its economic potential with the development direction that has been arranged (Haryani \& Setiyowati, 2018).

Many previous studies on SME development associated with innovation and public-private sector partnerships have been carried out (Broechler, 2015; Dimitriyep, 2016; Halimani et al., 2019; Liboni, 2015; Mabuza, 2017; Moller et al., 2015; Sama , 2015). Most of these studies discuss the development of SMEs and public-private sector partnerships from the perspective of a country's national policy, in which the state has a strong power to intervene in the market through its economic policies. Meanwhile, no studies have been found that specifically discuss the effectiveness of implementing partnerships at the autonomous region (city / district) level. Whereas, in fact, the basis of UKM is at the regional level. Therefore, this study is important to capture the real conditions of SME development and the effectiveness of public-private sector partnerships in Depok City for the period 2018-2020, with all the complexity of the problems at the grass root level. That is why the originality of this study appears and can enrich references for SMEs, the private sector, and for the government in making policies related to SME development through public-private sector partnerships.Majalah Ilmiah Bijak Vol 1 , No. 1, Maret 2018, pp. xx$\mathrm{xx}$

\section{METHOD}

This study was conducted using a qualitative descriptive approach, by capturing the phenomenon of SME innovation strategies in Depok City through public-private sector partnerships. The duration of the study is seven months, starting from September 2019 - April 2020. Interviews were conducted with twenty-four informants consisting of twenty-two UKM players spread across eleven sub-districts in Depok City, and two informants from the Depok City Cooperative and UKM Office. The interview took about thirty minutes for each informant. The information obtained from informants is related to the policies taken by the Depok City government in advancing SMEs, the innovation strategies carried out for the development of SMEs, and the extent of support to build partnerships with other stakeholders. Observations were made at the location where the UKM was operating, by looking at the physical condition of the UKM's existence, for example the booths in the supermarket, and also seeing firsthand the activities of the product manufacturing process. Literature study is carried out by collecting documents such as laws and regulations and regional regulations relating to the SME sector. Secondary data collection is intended to enrich understanding of all policies related to SME innovation strategies and publicprivate sector partnerships. After the data is collected, it is analyzed, and finally conclusions and verification are drawn. Data analysis is carried out by organizing the data, describing it into units, arranging them into patterns, then choosing which ones are important to study in order to make it easier to understand what happened. After that it was concluded. The initial conclusions put forward are still provisional and will change if strong evidence is found to support the next stage of data collection. But if the conclusions put forward at the initial stage are supported by valid and consistent evidence, then the conclusions put forward are conclusions. credible.

\section{RESULTS AND DISCUSSION}

Today's global competition actually provides two choices for the business sector, namely to innovate or die. Likewise, the SME sector in the city of Depok is increasing rapidly with less diversified business. In 2020, there were 2,385 SMEs carrying out business activities in Depok City 
(Satu, 2020). The ability of SMEs to innovate is a problem in itself, moreover, the SME sector is still synonymous with the little people sector, which only does a modest business. These problems are partly caused by the lack of capacity of SMEs in innovating and building partnership networks. This is a big contribution to the ebb and flow of UKM in Depok City.

The results in the field show that from the many discourses that have emerged regarding support for the development of SMEs, most of the interested parties are more focused on improving financial access for SMEs. And it can be said that there are still few who provide support for innovation, let alone sharing knowledge about how to innovate. Wherever there is, innovation is only understood as an effort to replicate existing business products, not as the ability to create business novelties to increase the growth and competitiveness of SMEs in the global market. So it is not surprising that the business diversification carried out by SMEs is not optimal.Majalah Ilmiah Bijak Vol 1, No. 1, Maret 2018, pp. xx-xx

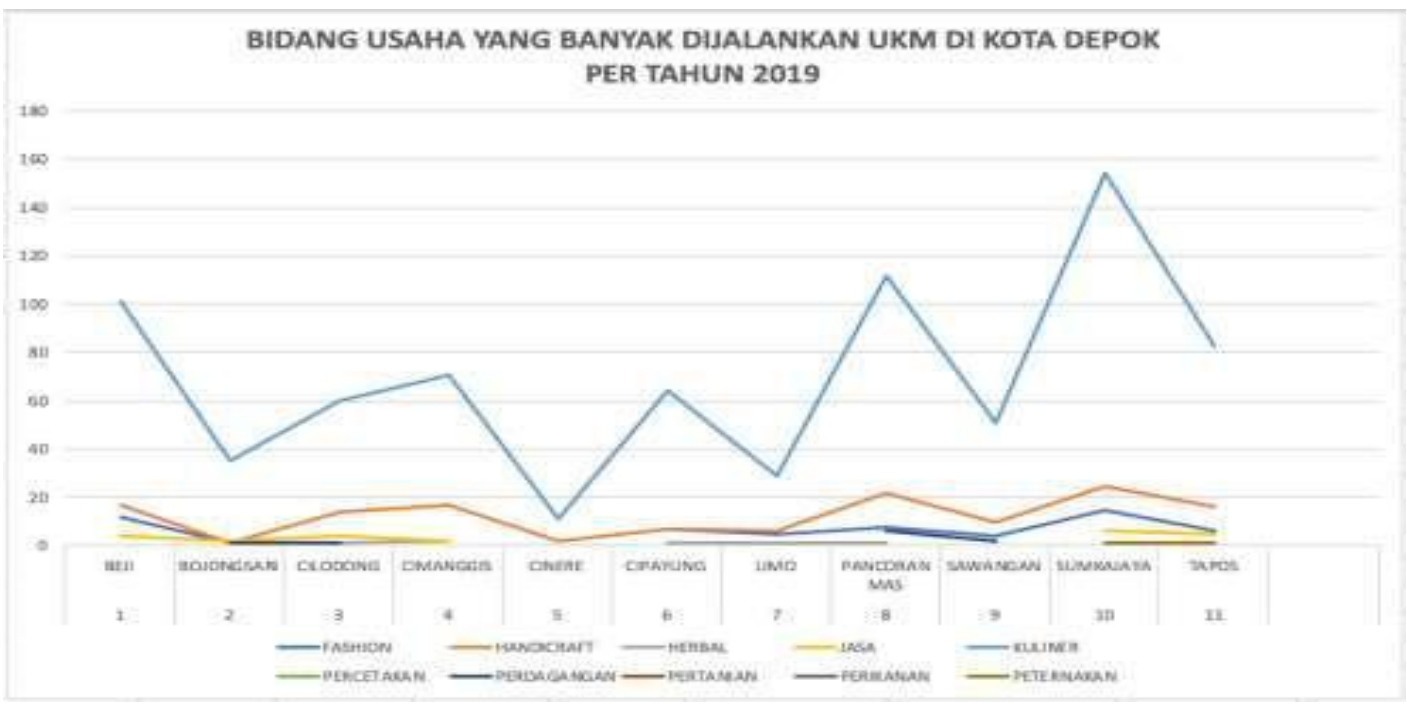

Fig. 1. The Business Fields that are mostly run by SMEs in Depok City in 2019 Source: Research Result, 2019

The data above shows that in 11 Districts in Depok City, it turns out that the business fields run by SMEs are mostly in the culinary sector. Business fields other than culinary are not very active and the numbers are small. The culinary sector tends to be popular considering the population in Depok City is quite dense, so business people are interested in pursuing the culinary business even though its existence has experienced ups and downs.

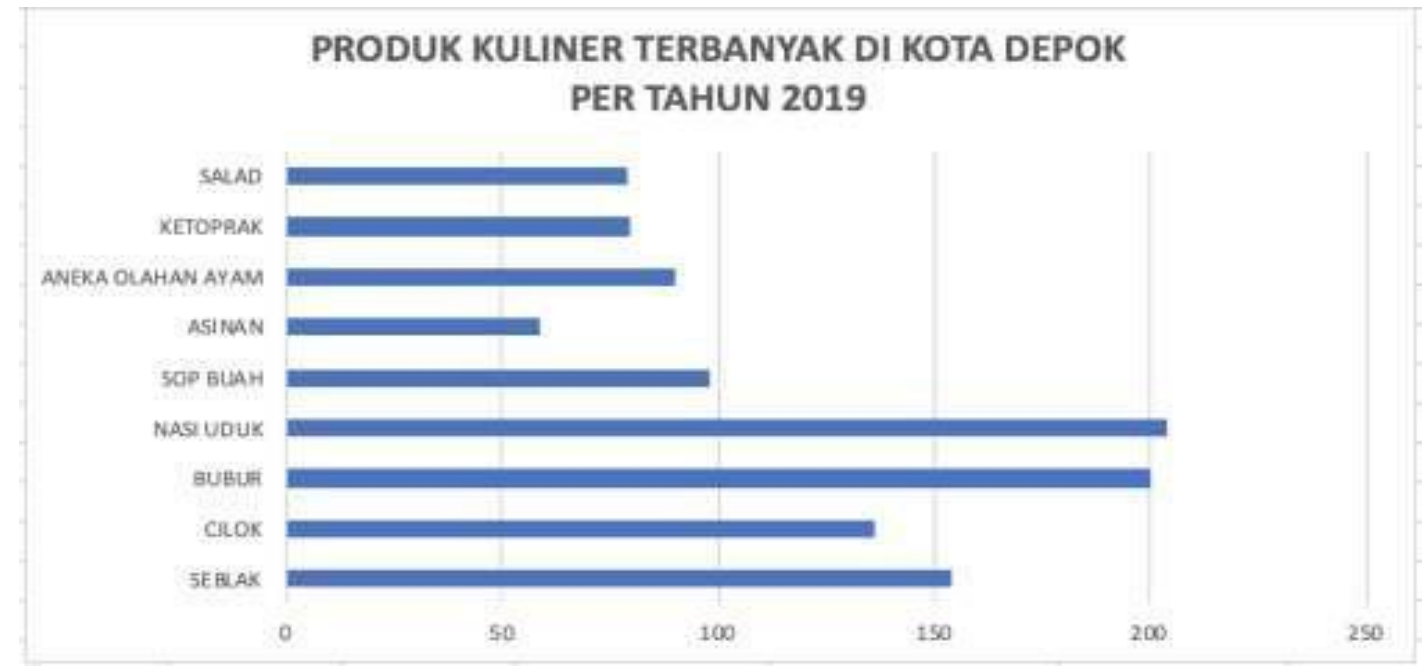

Fig. 2. The The Most Culinary Product in Depok City in 2019 Source: Research Result, 2019 
But for the culinary business, the types of culinary products being marketed tend to be the same. There was no specific diversification of each type of product. Starting from the packaging to the taste, it was almost the same. Types of products that can be marketed is said to be a replication of an existing product. So, although the local government focuses on the development of SMEs with its New Entrepreneurial Program, it has not been matched by attention to the aspect of innovation. Innovation is still jargon, which seems difficult to implement. Even though the innovation of a product is believed to be able to provide added value for SMEs. The results in the field also show that there is a gap in understanding the concept of innovation. UKM players still think of a simple business, which is important to sell, without thinking about innovation to increase added value which is very beneficial for the sustainability of their business. This conventional pattern of thinking is one of the reasons why SMEs are unable to compete and are vulnerable to market challenges.

Because of that, the efforts of the Depok City government to open opportunities for partnerships between the public-private sector are expected to accelerate the growth of SMEs in Depok City. The partnership built by the Depok City Government involves the private retail sector such as Giant, Indomaret, Superindo, Alfamart. However, the partnerships that were built were still not able to touch the innovation aspect. Partners only make SMEs limited to small traders who are given land around the retail location of the business, given a special booth and subject to rent. There are no mentoring efforts to make innovation yet. Even though innovation exists as a logical consequence of the dynamics of problems and needs that are always present and increasing..

The results showed that the innovation capacity of SMEs in Depok City after the partnership was built was still far from what was expected. The Depok City Government must of course be realistic, that it is still difficult to bring SMEs to a wider market. In this case, a more operational policy is needed regarding SMEs in partnership networks. SMEs are not only seen as ordinary traders who are given land to sell, but must also be fostered so that their business products can compete, namely by providing knowledge about product innovation (Ruchkina et al., 2017). In fact, partnerships like this are the key that can be utilized to increase expertise capacity, increase cost efficiency, and can create broader economic growth (Alen \& Shepherd, 2014; Mabuza, 2017).

In the context of a policy, it is necessary to have a clear policy design related to innovation and partnership strategies in the development of SMEs. This policy design is used to better understand the nature of the problems at hand, and to formulate policy goals and objectives. These last two things are the basis for formulating alternative policy interventions that the Depok City government can do for the development of SMEs.

\section{CONCLUSION}

Public-private sector partnerships have not had a significant impact in encouraging the development of SME innovation in Depok City. Public-private sector partnerships are only limited to providing supporting infrastructure and do not touch on anything substantial. In fact, what SMEs need most is technical assistance in continuous innovation such as creative branding and online marketing training, experiential marketing strategy, green business strategy, so that they are able to produce products that are no less competitive in a wider market. In addition, the main focus of this partnership is only limited to the level of increasing income for SMEs, which is only temporary. Even though this partnership should be able to support the long-term sustainability of businesses run by SMEs so that they can have a wider impact on the economy of Depok City. 


\section{REFERENCES}

Alen, S., \& Shepherd, B. (2014). The Government' s role i n filling the gaps of support to SMEs in Mozambique. International Journal of Latest Research in Humanities and Social Science, 01(03), 64-72.

Balkans, W. (2019). Support services for SMEs (Dimension 5a) in the Western Balkans and Turkey. https://doi.org/10.1787/a364aba8-en

BPS. (2019). Produk Domestik Regional Bruto Kota Depok 2015-2019. Retrieved from https://depokkota.bps.go.id/publication/download.html?nrbvfeve=NWU1YTgzM2FkNjU1MTJj Mjc2ZTE1NDlk\&xzmn=aHR0cHM6Ly9kZXBva2tvdGEuYnBzLmdvLmlkL3B1 YmxpY2F0a W9uLzIwMjAvMDUvMjkvNWU1 YTgzM2FkNjU1MTJjMjc2ZTE1NDlkL3Byb2R1ay1kb211 c3Rpay1yZWdpb25hbC1icnV0by1rb3RhLWRlcG

Broechler, R. (2015). Public-Private Partnerships (PPPs) - an instrument to better involve SMEs and industry. Conference: 2015 Daejeon Global Innovation Forum. Retrieved from https://www.researchgate.net/publication/293743508_Public-Private_Partnerships_PPPs__an_instrument_to_better_involve_SMEs_and_industry

Business, I. (2016). Supporting SME Growth through Innovation and Partnership - Business

Fights Poverty. Retrieved August 22, 2020, from https://businessfightspoverty.org/articles/supportingsme-growth-through-innovation-and-partnership/

Dewi, M. P., \& Tuswoyo. (2020). Mewujudkan Kemitraan Publik-Swasta dalam Pemberian Layanan Pendidikan di Kota Tasikmalaya. Jurnal Reformasi Administrasi, 7(1), 50-55. Retrieved from https://ojs.stiami.ac.id/index.php/reformasi/article/viewFile/947/525

Dimitriyep, S. (2016). Public-private partnerships ( ppp ) for sme development.

Halimani, D., Mazava, T., \& Dzapasi, F. D. (2019). The potential impact of public-private partnerships in developing the small to medium sector in Zimbabwe 1. PM World Journal, $\operatorname{VIII}(\mathrm{Xi}), 1-8$.

Haryani, I., \& Setiyowati, H. (2018). Strategi pengambangan usaha kecil dan menengah. (B. Harlis, Ed.). Depok: CV. Landasan Ilmu.

Hussain, I., Sib, S., \& Wangc, L. (2010). SMEs Development in Developing Countries through Public-Private Partnership. African Journal of Business Management, 6(4), 1581-1589.

Janda, K., Rausser, G., \& Strielkowski, W. (2013). Determinants of profitability of polish rural microenterprises at the time of EU accession. Eastern European Countryside, 19(1), 177-217. https://doi.org/10.2478/eec-2013-0009

Liboni, C. R. (2015). The role of Government in enhancing the growth and development of SME through a better use of the Intellectual Property System. Moscow, Rusia.

Mabuza, P. (2017). A PPP Model for Developing a Sustainable SME Sector in Developing

Majalah Ilmiah Bijak Vol 1, No. 1, Maret 2018, pp. xx-xx

Countries. Second International Conference on Public-Private Partnerships, 516-533. Retrieved from https://ascelibrary.org/doi/pdf/10.1061/9780784480267.040

Moller, K., Partanen, J., Rajala, A., Wasterlund, M., Rajala, R., \& Svahn, S. (2015). Role Partnership and Networks In Sme Innovation and Growth. Imp Group. Retrieved from https://www.impgroup.org/paper_view.php?viewPaper=4731

Niño-Amézquita, J., Dubrovsky, V., \& Jankurová, A. (2017). Innovations and competitiveness in regional development: a comparison of Latin America, Europe, and China. Czech Journal of 


Social Sciences, Business and Economics, 6(1), 28-36.
https://doi.org/10.24984/cjssbe.2017.6.1.4

Ruchkina, G., Melnichuk, M., Frumina, S., \& Mentel, G. (2017). Small and medium enterprises in the context of regional development and innovations. Journal of International Studies, 10(4), 259271. https://doi.org/10.14254/2071-8330.2017/10-4/20

Sama, H. K. (2015). Leveraging Opportunity Exploitation and Public Private Partnership :

A Review of SMEs Perspectives, 4(6), 292-300.

Satu, B. (2020). Pemkot Depok Siapkan Strategi Bangkitkan UMKM. Retrieved August 24,

2020, from https://www.beritasatu.com/feri-awan-hidayat/megapolitan/659427/pemkot-depoksiapkan-strategi-bangkitkan-umkm

Sitharam, S., \& Hoque, M. (2016). Factors affecting the performance of small and medium enterprises in KwaZulu-Natal, South Africa. Problems and Perspectives in Management, 14(2). https://doi.org/10.21511/ppm.14(2-2).2016.03

UNIDO. (2004). Partnerships for Small Enterprise Development. Deloitte. Retrieved from http://www.unido.org/fileadmin/user_media/Publications/Pub_free/Partnerships_for_s mall_enterprise_development.pdf

Vanags, A., Ābeltina, A., \& Zvirgzdina, R. (2018). Partnership strategy model for small and medium enterprises. Problems and Perspectives in Management, 16(1), 336-347. https://doi.org/10.21511/ppm.16(1).2018.33

Internet Sources:

https://www.depokpos.com/2019/03/pemkot-depok-rampungkan-pembuatan-623-kios-umkm/ https://tirto.id/kadin-sebut-ada-30-juta-umkm-tutup-akibat-pandemi-covid-19-fUa4 